\title{
農村住居の住まい方を通してみた私的な生活行為とその空間 \\ A STUDY ON PRIVATE SPACE AT RURAL HOUSE BY RESEARCH LIFESTYLE
}

\author{
岡部 雅 美*1, 伊藤 庸一*2 \\ Masami OKABE and Yoichi ITO
}

\begin{abstract}
In this paper we will clear up the private space at rural house in which the extended family have lived. We cleared as follows:

1) The child is given private room one grows older, and the child has keeping private room when one grows up to be a fine young man. The other family member have keeping private room. That is to say, there are two cycles that each family member have the private room.

2) The couple and old family member have private room. In addition, they have used family roon by way of private room. But the private space of cild has oneself.

3) The family member that has two private rooms know how to use properly each room.

4) The each family hope the private space which be done lifestyle on many various.
\end{abstract}

Keywords: rural house, extended family, lving with family, lifestyle. diversification of private lifestyle, private space

農村住居、通世代家族、同居、住まい方、私的な生活行為の多様性 私的空間

1. 研究の背景と目的 かつて日本では、個人や個室な ど「個」を主張する考え方はあまりみられなかった。し かし、近代化以降、「個」の概念への関心は高まり、個 人や個室といった考え方が尊重されてきた。1989年 「すまいの近代化論」"'をテーマとして開催された日本 建築学会大会協議会では、近代化における「個人」の確 立が家族観や住空間構成に多大な影響を及ほしたことを 指摘している。また、こうした現象は農村住居で行われ てきた、個室要求に応じた住居の改築にも表れている゙2。 前稿"3では、「個」の概念が主張される中での通世代 家族の現代的な住まい方の特徽を生活単位（生活主体） ${ }^{*}{ }^{4}$ と住まい方を通して検討した。その結果、家族一緒の 団らんや食事に加えて、核家族単位や夫婦単位で団らん や食事が行われていること、そしてこうした生活単位の 重層性が空間構成に影響し、団らんや食事の部屋が重層 的に確保されていることを求めた。

「個」は、もともと個人（ひとり）や個性を主張する 概念であるが、現代の通世代家族の住まい方の検討から、 「個」という考え方は核家族や夫婦などの集合体にもあ らわれていることがわかる。つまり、夫婦や核家族など が集合体の「個」を尊重した結果、夫婦や核家族単位で
の団らんや食事が行われ、それぞれの行為に応じて部屋 が重層的に確保されてきたと考えられる。このことから、 これまでの個室の考え方だけでは生活主体の「個」を充 足することはむずかしく、生活主体の私的な生活行為 ${ }^{* 5}$ を行う私的空間が必要であることが示唆される。

これまでの研究をみると、「個」の概念に関する研究 では、西山卭三の「日本のすまいII」"6をはじめ農村住 宅の「個室」要求に応じた住宅改善に関する研究が多く みられる。また、大岡敏昭"7恃農村の住居には夫婦寝室 （ナンド）が確保されていたことを指摘している。また 「個」に類似する概念では「私」や「我」があげられる。

「私」に関する研究では西山吅三の「住居論」" ける公私室型研究が最初であろう。西山は住空間を私室 と公室にわけて住空間論を展開した。この論を踏まえ、 鈴木成文 ${ }^{*}$ が「私室」「公室」について検討し、二公室 論を提示している。また、竹下輝和他 ${ }^{* 10}$ は「子供部屋 ・主寝室」を「私室」とし、公と私の空間領域を人間関

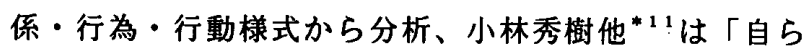
気に入るように場を飾り、しつらえ、維持を行う」空間 を「専有私室」とし、場の領域のしつらえや維持管理を 指標として考察している。

\footnotetext{
*1 日本工業大学建築学科 特別研究員 $\cdot$ 工修

Postgraduate, Dept. of Architecture, Nippon Institute of Technology,

*2 日本工業大学建築学科 教授・工博 M. Eng. Prof., Dept. of Architecture, Nippon Institute of Technology, Dr. Eng.
} 


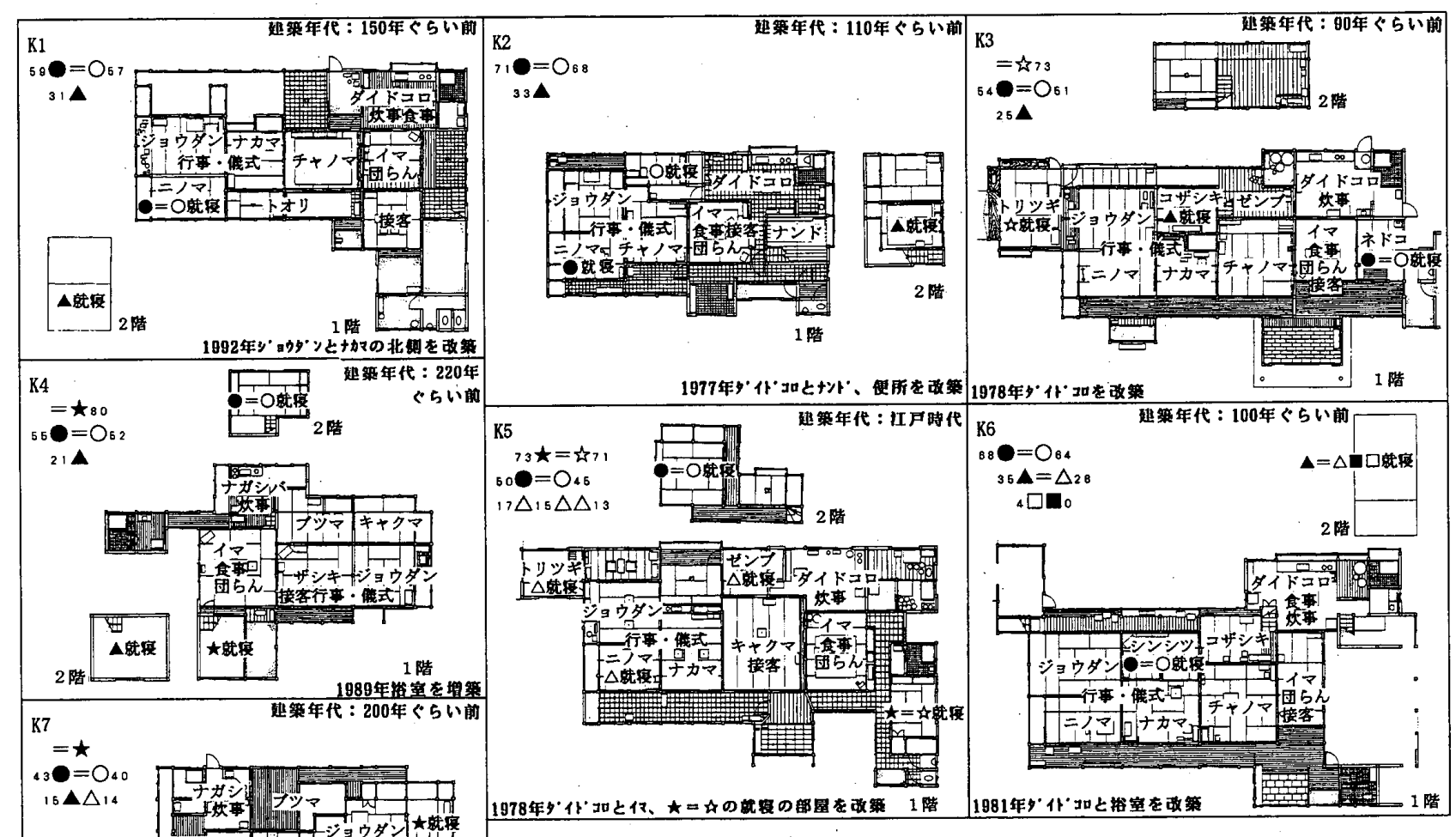

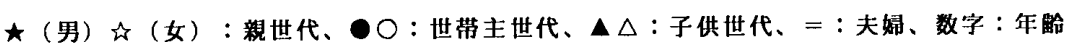
（無記入は未調查）、部屋呼称は加㔹で示す、K1〜K7は事例番号、なお建築年代はヒアリンク に得られた回答であり、明確な年代は不明。

図 1 対象住居の間取りと住まい方

「我」に関する研究は持田照夫の「俋態論」*12 にみ られる。持田が提唱した「我」は「生活自身の自己主張 我」を示しており、生活主体の我が主張される生活行為 が指標となっている。

以上、これまでの「私」「個」「我」の概念を整理す ると、(1)「私」「個」「我」の概念は一様でないこと、 (2)「私」は就寝という生活行為を主な指標とする概念、 「個」は夫婦に対する子供を指標とする概念、「我」は 生活主体の我に応じた生活行為を指標とする概念であっ たことがわかる。前述したように、近年、家族観が多様 となり、加えて住まい方観の多様化が見られる。多様な 家族観あるいは住まい方観が波及している今日の私的な 生活空間を解明するには、生活主体と生活行為を対応さ せてとらえなければならないのではないだろうか。

そこで、本稿では農村住居の通世代家族を取り上げ、 生活主体別に私的な生活行為を検討し、私的空間は多岐 にわたる私的な生活行為を充足すべき空間であること、 そして、生活主体は私室を中心に家族共用の部屋に依存 するかたちで私的な生活行為を充足していることを明ら かにする。

2. 研究の方法 通世代家族の住居での私的空間を解明 するには、まず、私的空間がどのように確保・確立され ているかをとらえなければならない。そこで、(1)家族社
会学で家族生活を観察するときに用いられている段階設 定法*13を用い、子供の成長に応じて 5 段階を設定し、 私室"14 のとられ方を求める。次に(2)確保・確立された 私室での在室時間、および私的な生活行為の行われ方を 生活主体別にとらえ、私的空間の構成を検討する。さら に、(3)年代別に住まい方に対する志向をとらえ、多様な 生活行為に対応した私的空間の必要性を求める。

対象地は、通世代家族が多くみられる山形県"15 とし、 農業従事者が多く、地域固有の住居が多く分布している 高畠町上和田地区 ${ }^{* 16}$ を事例地に、地域固有の平面構成 をみせる 7 事例（因 1）を取り上げ、間取り採図調査な らびに家族構成、部屋呼称、住まい方、私室のとられ方 などに関するヒアリング調査（1992年8月実施）、およ び上和田地区全戸（77戸）の世帯主と次世代に対するア ンケート調査（1992年8月実施）を実施した。

3. 私室のとられ方子供の成長に着目して、第 I 段階 =結婚～第 1 子誕生、第 II 段階＝第 1 子誕生～小学校入 学、第吕段階＝小学校入学～小学校卒業、第 $\mathrm{V}$ 段階 $=$ 中 学校入学〜高校卒業、第 V 段階=高校卒業〜結婚の 5 つ の段階を設定し、それぞれの段階での私室のとられ方を 親世代（現世帯主の親）、世帯主夫婦、子供（現世帯主 の子供）にわけてとらえた（図 2 ）。

まず、第 I 段階は結婚したばかりの現世帯主夫婦と親 


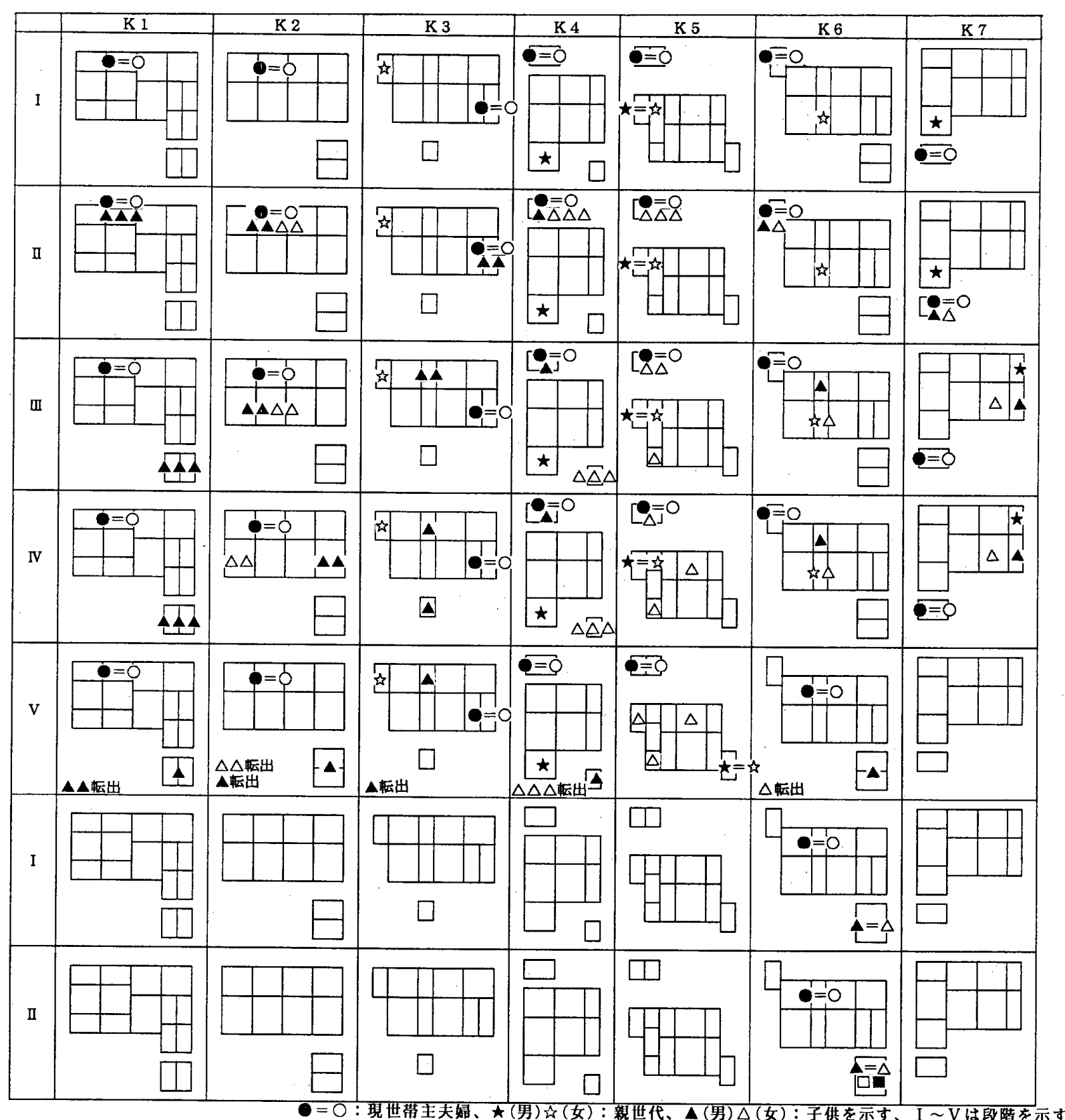

図2 子供の成長段階を通してみた私室のとられ方

世代の段階である。現世帯主夫婦はコザシキ（K1、K2） や2階(K4、K5、K7)、ネドコ(K3)、トリッギ(K6)などに

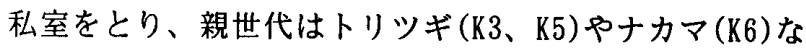
どに私室を確保している。第 II 段階は子供が生まれ家族 が增えた段階である。生まれた子供は親である世帯主夫 婦と一緒に就寝する。世帯主夫婦、親世代いずれもこの 段階での私室の移動はみられない。第而段階は子供が親 元から独立し始める段階である。K1ではきょうだい 3 人 が一緒に独立し、2 階の部屋に私室をとる。K2ではきょ うだい 4 人でナカマに移動し、私室を確保する。K3では コザシキにきょうだい 2 人で移動し、K4では第 4 子は世 帯主夫婦の部屋に残るが、他のきょうだい 3 人は 2 階に 私室を移動する。K5は第 1 子がニノマに私室をとり、他 のきょうだいは親元に残る。K6では女の子は祖母の部屋 に移動し、男の子は独立してひとりで私室をシンシツに
とる。K7ではこの段階で子供が独立し、ニノマとその隣 の部屋にそれぞれ私室を確保する。つまり、この段階で は、子供は世帯主夫婦の私室から独立し、きょうだいま たはひとりで私室をとるようになる。第 V 段階は子供は 異性を意識し始める段階である。K1あるいはK4では私室 の移動はみせないが、K2では同性のきょうだいにわかれ、 姉妹はニノマに、兄弟はナンドに私室を移動する。K3で はこの段階で第 1 子がこれまでの部屋を専用の私室とし、 第 2 子が 2 階に私室を移動する。またK5では第 2 子が親 元を離れ、独立してゼンブに私室を確保する。つまり、 この段階では同性のきょうだいにわかれ、それぞれ私室 をもつようになるか、または、独立してひとりで私室を 確保するようになる。第V段階になると、K1、K2、K3、 K4では第 1 子以外の子供が転出し、残った子供は第 $\mathrm{N}$ 段 階で私室として利用していた部屋をそのまま利用する。 
また、K6ではこの段階で残った子供が 2 階に私室を移動 している。K5では子供の転出はみられず、この段階で第 3 子が親元から独立し、トリツギに私室を確保する。卜 リツギを私室としていた親世代はイマの近くの部屋に私 室を移動させる。つまりこの段階では、それぞれの子供 が独立し、転出あるいは私室専用を持続する。そして、 私室専用を持続した子供が結婚をすると、第 I 段階に戻 る。調査時点ではK60 1 事例しかみられないが、K6では 子供は結婚すると第 V段階でひとりで利用していた私室 を夫婦の私室として利用する。さらに、子供が生まれ第 II 段階になると、そのまま夫婦の私室で子供が一緒に就 寝する。

一方、子供が独立した世帯主夫婦は、いずれの事例も 子供の成長に応じて私室を移動することはない。しかし、 親世代の他界をきっかけに、K6のように夫婦の私室をト リッギからシンシツに移動したり、K2のように妻がこれ までの夫婦の私室をそのままひとりで利用し、夫がニノ マに私室を移動する場合もみられる。

以上をまめると、(1)子供は成長するにしたがって、核 家族いきょうだいい同性のきょうだいいひとりという経 緯を踏まえ、部屋を移動しながら、私室を確保・確立す る。(2)夫婦は第正段階以降、子供の成長に左右されずそ のまま私室を利用するが、親世代の他界などが契機とな って部屋を移動する場合もある。つまり、私室のとられ

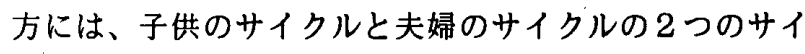
クルがあり、子供のサイクルと夫婦のサイクルが連動し 私室が確保・確立される（図3）。

4. 生活主体別にみる私的空間の構成 私室に在室する 時間をみると（図 4) *17、8時間が20.4\%と多く、次い で14時間(17.6\%)、12時間 (16.1\%)、7 時間 (15.1\%)、9 時間(15.1\%)が多くみられ、1/3〜1/2日も私室に在室し ていることがわかる。そのあいだどのような生活行為 ${ }^{* 18}$ を行っているかをアンケート調査結果をもとに整理 した（図 5 )。その結果、くつろき（60.9\%)、本や新 聞を読む $(50.1 \%) 、$ テレビをみる $(47.7 \%)$ などのくつ ろぎ行為に加え、友を招く（23.5\%）や電話をかける（1 $7.0 \%)$ などの家族以外の人との交流、勉強や仕事 $(21.3$ \%)、食事 $(17.2 \%)$ 、非日常的なもてなし行為（誕生会 をひらく=2.2\%) など、多様な生活行為が行われている ことがわかった。

次に私室の使われ方の実態を把握するためヒアリング 調査*19で得られたデー夕を生活主体別に整理し、私的 空間の構成と住まい方をとらえた（図6）。

(1)核家族 核家族で私室をもつ事例はK 6 の 1 事例である。 K6の核家族は 2 階の 10 畳と 3 畳の 2 部屋を私室として利 用している。私室の使われ方をみると、10畳の部屋で、 就寝やくつろぎ、本や新聞を読む、テレビをみる、仕事、 団らん、ビールなどを飲む行為を行っている。対して 3

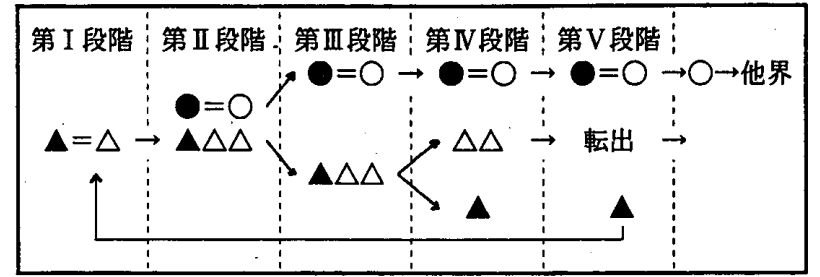

- (男) $=0$ （女）：世帯主夫婦、 $\Delta \Delta ：$ 世帯主夫姼の子供

図3私室のとられ方のモデル

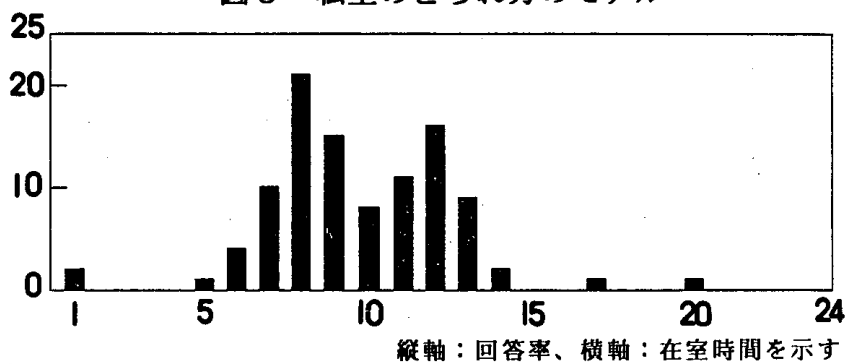

図4 私室での在室時間

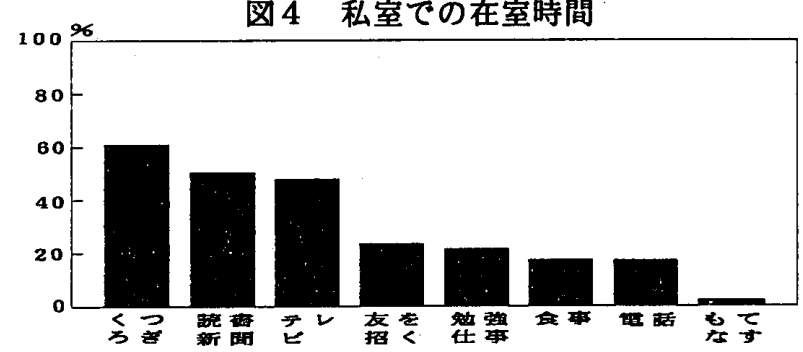

図 5 私室で行われる生活行為

畳の部屋を主として更衣・収納に利用しており、2 部屋 の使いわけがみられる。なお、友を招くときは家族共用 のイマで行い、電話は家族共用の電話を用いている。

(2)夫婦 1 部屋の私室をもつ事例 $(K 1=7.5$ 畳、 $K 3=6$ 畳、 $K 4=7$ 畳、K6=6 盢、K7=6 畳) では、いずれも世 帯主世代、親世代を問わず、就寝、更衣・収納、くつろ ぎ、本や新聞を読むなどを私室で行う。テレビをみるや お茶を飲む、夫婦の団らんは家族共用のイマ（K1、K3、 K4、K5、K6) やダイドコロ(K7)で行われ、電話は家族共 用の電話を利用する。友を招くときは家族共用のイマ （K1、K3、K5、K6）やザシキ(K4、K7)を用いる。仕事は 主としてイマなどで行われ、私室で行われることはない。 また、夫婦でのもてなす行為は行われていない。つまり、 1 部屋の私室をもつ夫婦は、部屋の広さにかかわらず、 私室を中心にイマやザシキあるいは玄関など家族共用の 部屋を利用することで、夫婦の私的な生活行為を充足し ている。

8 畳と 3 畳の 2 部屋構成の私室をもつK5の世帯主夫婦 は、8畳で就寝や更衣・収納、くつろぎ、本や新聞を読 む、テレビをみる、仕事、食事、夫婦の団らんを行い、 3 畳でくつろぎ、本や新聞を読む、食事などを行ってい る。友を招くときは家族共用のザシキを利用し、電話は 家族共用の電話を用いる。夫婦でのもてなす行為は行わ れていない。つまり、2 部屋の私室をもつ夫婦は、2 部 屋を使いわけながらも、私室を中心としてザシキや去関 


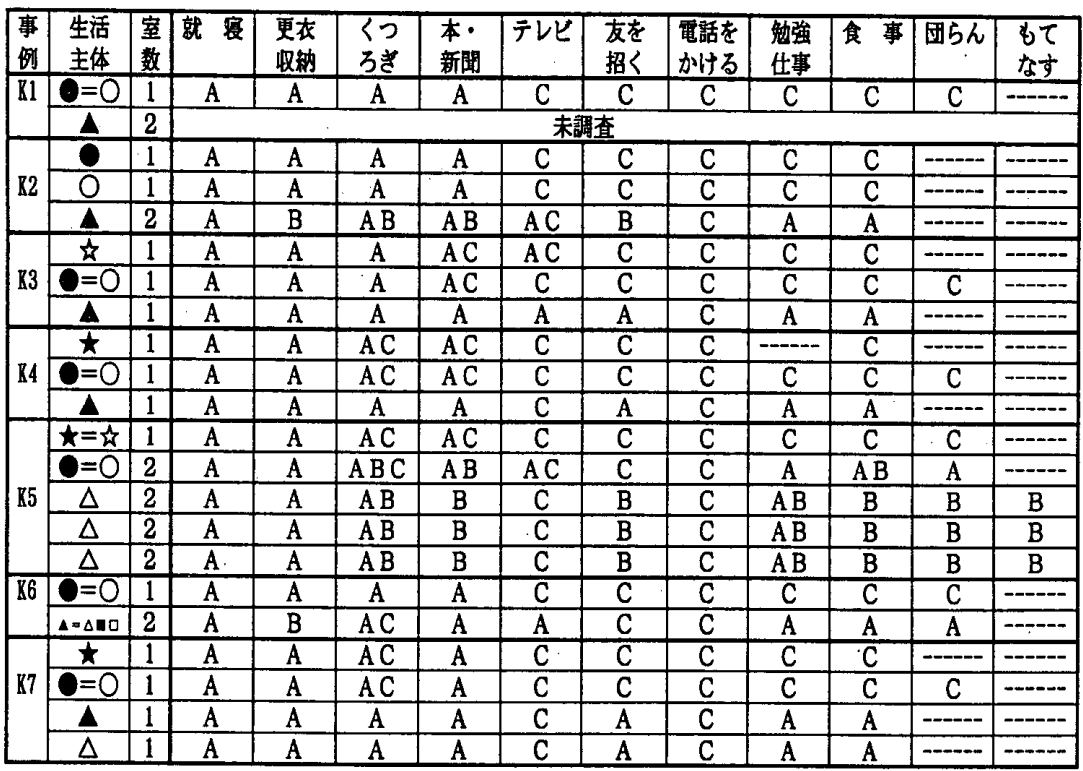

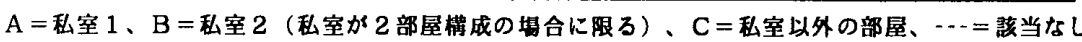

図 6 生活主体別にみる私的空間での住まい方

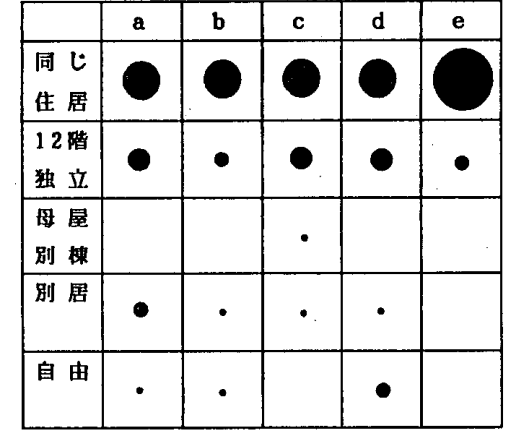

同し住居：同じ住居で助け合う生活、12隌 独立：母屋の1、2階なとある程度出立し、 団5ん户行事は共同て行方生活、母座别椫

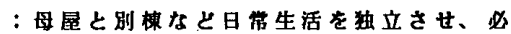
要に塘して母屋に集まれる生活、别居：别 々に住むが、困ったときすく助け合える揭 所で生活、自由：同居にこだわらない自 由な生活、 $a=65$ オ以上、 $b=64 \sim 50$ オ、 $c=49$

〜35才、 $d=34 \sim 20$ オ、e=19才以下、ロに内 接する・を100xとし、・は回答束を示す

図 8 通世代家族同居に対する志向
などの家族共用の部屋を利用することで夫婦の私的な生 活行為を充足している。

(3)ひとり 1 部屋の私室をもつ事例（K2=7.5睤、6 畳 $K 3=10$ 畳、 6 畳、 $K 4=6$ 畳、10畳、K7=6 畳) では世代 を問わず、就寝や更衣・収納、くつろぎ、本や新聞を読 むを私室で行っている。テレビをみるは、世代にかかわ らず私室でみる場合と家族共用のイマでみる場合がある。 友を招くや勉強・仕事、お茶を飲むなどについては、親 世代あるいは世帯主世代は家族共用の部屋で行う傾向を みせるが、子供は私室で行う。電話は世代をとわず家族 共用の電話を用いている。ひとりなので団らんは行われ ない。また、もてなす行為も行われていない。

2 部屋を私室とするひとりはすべて子供である $(K 2=$

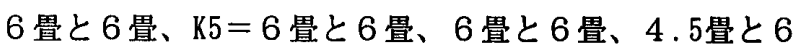
畳）。K2では 2 部屋のうち 1 部屋では、就寝やくつろぎ、 本や新聞を読む、テレビをみる、勉強・仕事、お茶を飲 むなどを行っており、もう 1 部屋は更衣・収納、友を招 くに主として用いている。電話は家族共用の電話を用い る。また、もてなす行為は行われていない。K5では 2 部 屋のうち 1 部屋（6 畕、6 畳、4.5冨）では、就寝や更 衣・収納、くつろぎ、勉強を行っている。もう 1 部屋 （6胃）はきょうだいで共用しており、本や新聞を読む、 友を招く、食事、もてなし（誕生会）に用いている。テ レビは家族共用のイマでみており、電話は家族共用の電 話を利用している。

以上より、(1)核家族では 2 部屋の私室を使いわけなが ら、私室を中心に家族共用の部屋を用いて接客を行い、 核家族単位の私的な生活行為を充足している。(2)夫婦の 場合、私室が 1 部屋、2 部屋にかかわらず、また、世代 をとわず、私室を中心として家族共用の部屋で接客など を行い、夫婦単位の私的な生活行為を充足させる。(3)
とりのうち世帯主世代や親世代の場合は、夫婦の場合と 同様の傾向をみせるが、子供は私室で私的な生活行為を 充実させようとする傾向が高く、私的な生活行為のため の家族共用の部屋の利用はあまりみられない。また、(4) 2 部屋構成の私室をもつ夫婦あるいはひとりは 2 部屋を 使いわける傾向が高い。つまり、世代、部屋数、部屋の 厷さを問わず、子供は私室で私的な生活行為を充足しょ うとし、親世代や世帯主世代のひとり、あるいは夫婦や 核家族は私的空間を家族共用の部屋に依存することで、 多岐にわたる私的な生活行為を充足している（図 7）。

5. 家族の住志向にみる多様な生活行為に応じた私的空 間の必要性 年代別 $(a=65$ 才以上、 $b=64 \sim 50$ 才、 $c=49$ 〜 35才、 $d=34 \sim 20$ 才、 $e=19$ 才以下）に住志向をとらえ、多 様な生活行為に対応した私的空間の必要性をとらえる。 (1)通世代同居に対する志向（図8）いずれの年代も 「同じ住居で助け合いながら生活すべき」（a=45.5\%、b $=50.0 \% 、 c=33.3 \% 、 d=46.7 \% 、 e=83.8 \%)$ 、次いで「 1 ・ 2 階である程度独立しながらも団らんや行事などは共同 で行える生活がよい」（a=27.3\%、b=22.7\%、c=33.3\%、d $=26.7 \% 、 e=16.7 \%)$ を高く志向しており、通世代同居を 高く評価している。

(2)通世代同居の住まい方志向 通世代家族が同居すると きの部屋の使い方について独立したい部屋志向と共用し た部屋志向をとらえた。まず前者の独立したい部屋志向
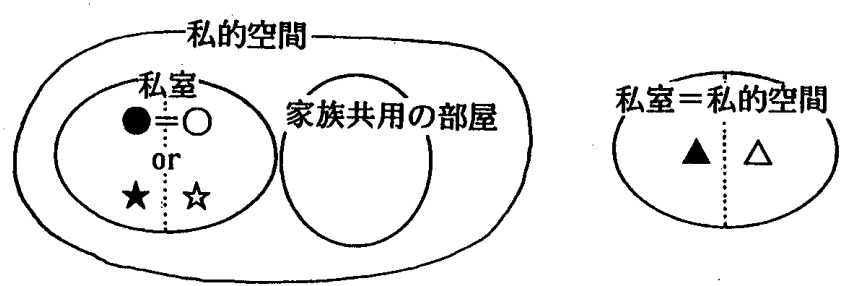

因 7 私的空間の確保形態モデル 
をみると、 $\mathrm{a} \sim \mathrm{e}$ いずれの年代も就寝室をあげ、次いで b、 $\mathrm{c} 、 \mathrm{~d} 、 \mathrm{e}$ が接客室、 b と c と d が団らん室を志向 しており、これまで家族共用の部屋として認識されてき た接客室や団らん室を独立させたいとする志向が高い。 このことは、私的空間にも接客や団らんの場が必要であ ることを示唆する。次に後者の共用したい部屋志向をみ ると、 $\mathrm{a} \sim \mathrm{e}$ いずれの年代も食事室、団らん室、玄関を あげており、次いで a、c、d、eが炊事室を、a、b、 c、eが便所を、eが行事室をあげている。独立志向の 高かった接客、団らん室が共用したい部屋志向にも表れ ており、団らんや接客の場が複数必要であることをうか がわせる。

以上をまとめると、年代にかかわらず通世代家族の同 居志向は高く、食事室や炊事室、浴室、便所、玄関を共 用しながら、就寝室は独立させ、接客室や団らん室を家 族共用の部屋と専用の部屋、数室もうける住まい方志向 がうかがわれる。このことから、私的空間は就寝室にと どまらず接客室や団らん室としての役割が必要であるこ とが示唆される（図9）。

6. まとめ 通世代家族が暮らす農村住居では、(1)私室 は子供のサイクルと夫婦のサイクルが連動し、確保・確 立される。(2)核家族、夫婦あるいはひとりで私室をもつ 親世代は、部屋数にかかわらず、私室を中心に家族共用 の部屋を私的な生活行為に利用することで、私的な生活 行為を充足する。(3)とりで私室を確保する子供は、部 屋数にかかわらず家族共用の部屋で私的な生活行為を行 わず、私室の中で私的な生活行為を充足する。(4) 2 部屋 構成の私室をもつ場合は生活主体を問わず、1 部屋を主 として就寝やくつろぎなどに、もう 1 部屋で更衣や収納 など私室を使いわける。

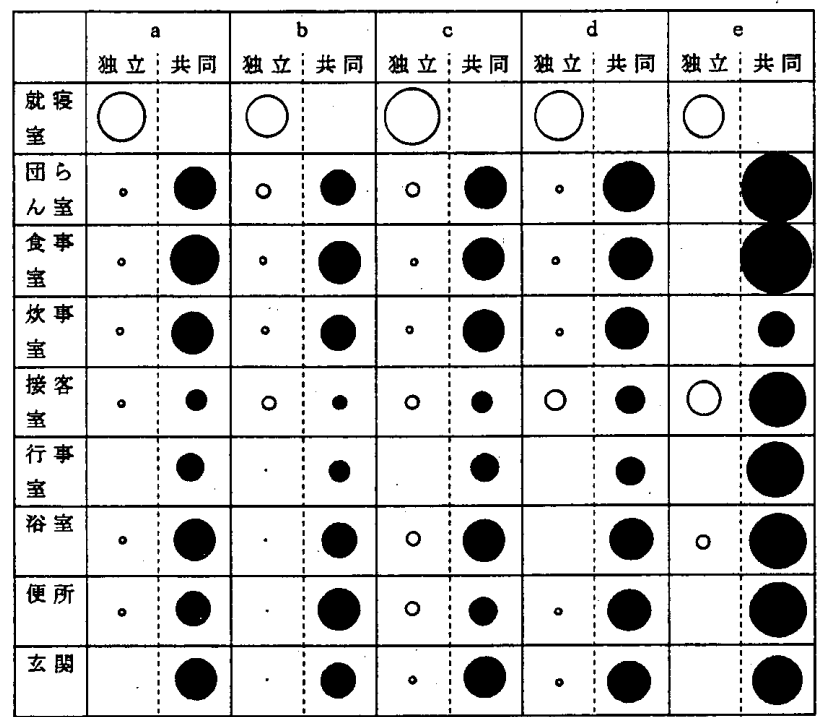

独立：別々にしたい部屋、共同：共用したい部屋、ロに内接する○ (O) 100\%とし、・（○）でそれそれの回答本を示す。

図9通世代家族の住まい方志向
すなわち、これまで私的空間は就寝を主とする専用の 部屋としてとらえられてきたが、生活主体のくつろぎや 勉強・仕事、団らんや接客、食事など多岐にわたる私的 な生活行為に対応すべき空間であることがわかった。子 供は 1 〜 部屋の私室で多岐にわたる私的な生活行為を 充足するが、夫婦や核家族あるいは親世代は、私室と家 族共用の部屋を私的空間とし、多様な私的生活行為を充 足する。

\section{謝辞}

末筆ながら、調査にご協力いただきました調査対象の 皆さまに心から感謝申し上げます。

\section{参考文献・注}

* 1 日本建築学会建筑計画委員会：すまいの近代化詥、日本建筑学会、 1989年

*2 岡部雅美、伊藤庸一：伝梳的住居における 3 世代の住み方について、 日本建築学会関東支部研究報告集、pp.292 232、1989年、他

*3雕部雅美、伊藤庸一：農村住居における生活単位之住まい方を通して みた通世代家旅の住空間、日本建穼学会計画系詥文集№.477、1995年

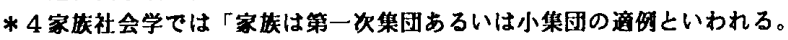
そのうえ、家旅は生活共同の単位として、生活の主体、つまり生活体でも ある」と定義している。この定義を引用し、住居内で生活行為を行う家族 成員の組み合わせを生活主体（前穆では生活単位）之定義した。例えは、 核家矮単位、夫妇単位など。（森岡清美他：新しい家族社会学、培風社、 pp.87、1991年 他)

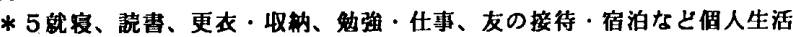
行為に加え、家族共同生活である食事、㰠事、団5ん、くつろぎ、テレビ、 新闑を讜を、電話、もてなすを生活主体が私的に行う坦合を含め私的な生 活行為とする。もてなすは主として生活主体が中心となって行う誔生会な

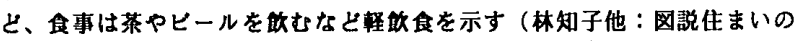
計画 住まい方から住空間をデザインする、乹国社、pp.16〜17、1991年) *6 西山吅三：日本のすまいI、到草费房、pp.267 292、1676年

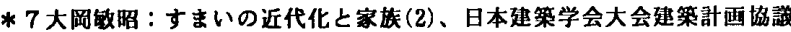
会、pp. 84 86、1989年

*8西山行三：住居稀、勁草書房、pp.550、1696年、

*9 祉木成文：住居における公室計两に関する研究、住宅建築研究所報、 （財）新住宅尊及会、pp.119 132、1981年

*10竹下辉和他：公私室型をめぐる、三の理論的諸閣題についてーその

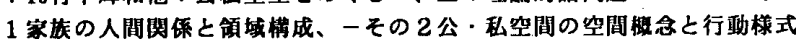
研究、日本建等学会大会学術梗概、pp. 59 62、1986年

*11小林秀樹他：領域諭による公私文化の研究に向けの方法の梌討－住様 式の領域詥的研究その 1、日本建築学会学術梗概、pp，207 208、1988年、

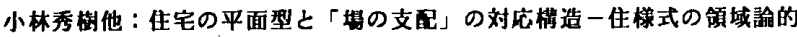

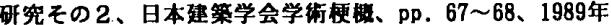

* 12持田照夫：俋昭論一新しい生活科学の提咱、学芸出版、pp.170 171、 1986年

*13家矢社会学で用いられている研究方法のひとつ。ここでは、第I 段䐗

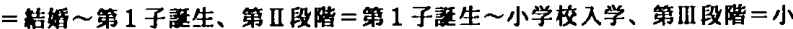

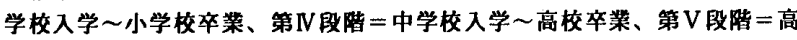
校卒業〜結婚の 5 つの段階を設定する（森岡消美他：新しい家族社会学、 培風社、pp.64 73、1991年)

*14生活主体（私）が就寝に用いる部屋を私室とした。本穆では夫妇や伭 家族なとの集合体の「佃」を、個人の個室と区別するため私室をを用いる。 *15山形県は、全国でも高䍅者率が高い。その反面、高峈者の单身世帯が

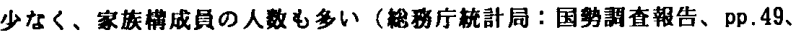
1985年、他）ことから、現在で通世代家笑が比敕的多い県と判断した。

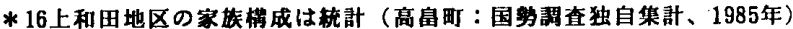

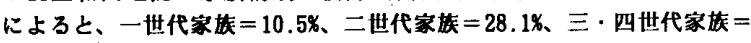

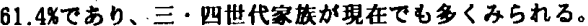
*17アンケート「一日のうちで、あなたが自分の部屋にいる時間带はいつ でか。昨日 (平日) の一日を記入して下きい」に対する回答 (自由祀入) *18广ンケート項目「自分の部屋では、就寝以外にどのようなことをして いますか」に対する回答（選抧肢を設定）

*19生活主体別に私的な生活行為（*5参照)についてのヒアリング請査 